\title{
People with Special Needs in Ancient Societies: A comparative Study between few Early Philosophers and Islam
}

\author{
Md. Sirajul Islam ${ }^{1}$, Sofiah Samsudin ${ }^{2}$ \\ *PhD candidate, Department of Qur'ān \& Sunnah Studies Studies, Kulliyyah of Islamic Revealed Knowledge and Human Sciences, International \\ Islamic University Malaysia, 53100 Jalan Gombak, Selangor, Kuala Lumpur, Malaysia. \\ ** Assistant Professor, Department of Qur'ān \& Sunnah, Kulliyyah of Islamic Revealed Knowledge and Human Science, International Islamic \\ University Malaysia, 53100Jalan Gombak, Selangor, Kuala Lumpur, Malaysia. \\ DOI: 10.29322/IJSRP.10.05.2020.p10137 \\ http://dx.doi.org/10.29322/IJSRP.10.05.2020.p10137
}

\begin{abstract}
This article focuses on people with special needs in ancient societies. The main aim of this article is to examine people with special needs in ancient societies as a comparative study between few early philosophers and Islam in order to find out the real circumstance and situation of this group of people. It focuses on three different ancient societies Europe, Arab, and India. This systematic investigation meets with ruthless and brutal decision of few philosophers, invalid notion of people; inhuman customs and picture of harassment towards disabled people in abovementioned societies. It attains only in the Holy Qur'ān and Prophetic traditions moral approaches in caring and empowering persons with special needs in early Islamic society in 7th century.
\end{abstract}

Index Terms- Special needs, injury, intellectually disabled, ancient societies, disadvantaged people, Islam, exclusion.

\section{INTRODUCTION}

$P^{\prime}$ eople who are suffering from with disabilities are among the world's poorest and most disregarded individuals. They face prejudice, stigma, exclusion, discrimination, and social isolation, and often deprived from the education opportunity, social integration support, and authorized right to appeal injustices at the family, community, or national level ${ }^{1}$.

Persons with special needs are those people who are suffering from an illness, injury or condition that makes it difficult for them to do some work that other people do easily ${ }^{2}$.

It is a dark chapter of disability history that persons with special needs had been depriving from their fundamental rights; there was

\footnotetext{
1 Groce, N. E., London, J., \& Stein, M. A. (2014). Inheritance, poverty, and disability. Disability \& Society, 29(10), 15541568.

2 Md. Sirajul Islam and Sofiah Bt. Samsuddin, (2018). Moral Approaches and Roles of Prophet Muhammad (S.A.W) In Empowering Persons with Special Needs. Australian Journal of Basic and Applied Sciences, 12(6): 30-35.

${ }^{3}$ Al-Jadid, M.S. (2013) Disability in Saudi Arabia. Saudi medical journal, 34(5), 453-460.
}

no life right for this group of people in ancient societies. People of Madinah used to prevent the lame and blind people from sharing food with them because they are deemed and repulsive ${ }^{3}$.

It is obvious throughout the history of humankind that societies treated and responded to people with special needs based on their cultural and belief systems ${ }^{4}$. For example, from ancient beliefs Neolithic tribes (9000 B.C.E - 3000 B.C.E) perceived person with disabilities as possessed by spirits (ghost). When the spirits were perceived as evil, escape routes were fashioned by drilling holes in the skulls of persons who were thought to be possessed $^{5}$. The Spartans, with their rugged individualism, abandoned young and old people with disabilities in the countryside to die ${ }^{6}$.

Stephen Covey (1932 A.D-2012 A.D) found that societies have commonly looked at people with disabilities in following ways: as subhuman or animal-like, supernatural or gifted, ugly, evil, meriting pity or charity, entertaining, indigent, depressed, child-like, dependent, sexually hyperactive, damaged, less socially acceptable, and socially deviant. They have also been perceived to be scapegoats, burdens, and liabilities to their societies. Cove also found several common explanations for disability throughout history including disability as a punishment from God for sin, a result of witchcraft and magic, a result of violence and accidents, the consequence of negative maternal feelings or parental misconduct during pregnancy, a hybridization of humans and evil spirits or animals, a normal side effect of process of aging or decay, and a product of astrological influences ${ }^{7}$.

This article deals with miserable phenomenon of people with special needs in ancient societies, opinion of few early

${ }^{4}$ Mackelprang, R. W., \& Salsgiver, R. O. (1996) People with disabilities and social work: Historical and contemporary issues. Social work, 41(1), 7-14.

${ }^{5}$ Albrecht, G. (1992) The disability business: Rehabilitation in America. Newbury Park, CA: Sage Publications.

${ }^{6}$ Mackelprang, R. W., \& Salsgiver, R. O. (1996). 41(1), 7-14.

7 Bhatty, I., Moten, A. A., Tawakkul, M., \& Amer, M. (2009)

Disability in Islam: Insights into theology, law, history, and practice. Disabilities: Insights from across fields and around the world, 1, 157-176. 
philosophers, and Islamic standpoints regarding disability. In terms of applying Islamic values within the context of disability will be studied from three different ancient societies and cultural perspectives- Europe, Arab and Indian society.

\section{IN EUROPE}

The history of West shows the phenomenon of neglect and harassment to persons with special needs that culminated in killing the disabled babies in few ancient European societies. The superstitious beliefs were responsible for this setback. For instance, it was believed that people those were suffering from intellectual and disabilities were possessed by devil and evil spirits. Even philosophers and scholars held such believed ${ }^{8}$. Before 2000 of the Common Era (BCE) with the cult of the 'body beautiful', the infanticide of disabled babies becomes common. Likewise, in Rome children with special needs are drowned in the Tiber, and people who considered being 'mentally defective' are prohibited from marrying 9 .

There is other evidence that the Romans believed people with disabilities as sub-human. In the early years of the Roman Republic (Ancient Rome 753 BC - AD 476), it was a customary practice to abandon a child who born with a disability due to both the supposed financial and divine burdens a child with disability brought ${ }^{10}$. In addition, Romans believed disability was negative "karma" of sorts - a supernatural sign of bad fortune to come. This was seen as good enough reason to rid a child with disability from a family ${ }^{11}$. Roman believed that disability was a mark of the Gods' displeasure. For this reason, a disabled child was frequently seen as a form of divine punishment upon its parents ${ }^{12}$.

\section{SOME FAmous EARly Philosophers' OpINION ABOUT PERSONS WITH SPECIAL NEED}

The renowned philosopher Plato (427 BC-347BC) came and declared that those who have special needs are a malicious category, and constituting a burden on the society, and a damaging factor to his Republic ${ }^{13}$. Aristotle (355 BCE) says that 'those born

${ }^{8}$ Muhammad, M.Y. The Prophet's Care for People With Special Needs, Available

in

http://www.usislam.org/islamicyouth/Muhammad/Prophet' s\%20Care\%20for\%20People.htm, Retrieved on 5 September, 2013.

${ }^{9}$ Andrew H. (2013) A Disability History Timeline The struggle for equal rights through the ages.

10 Brignell V. (2008). Ancient World, published on The New Statesman

http://www.newstatesman.com/blogs/crips-

column/2008/04/disabled-slaves-child-roman. See also: Will R. (2013) Disability in Ancient Rome, available in http://www.rootedinrights.org/disability-in-ancient-rome/, retrieved $17 / 5 / 2016$.

11 Will R. (2013) Disability in Ancient Rome, available in http://www.rootedinrights.org/disability-in-ancient-rome/, retrieved 17/5/2016.

12 Brignell V. (2008). Ancient World, published on The New Statesman deaf become senseless and incapable of reason ${ }^{14}$. The laws of the legendary lawmaker of Sparta, Lycurgus, and the Athenian philosopher and lawmaker Solon allowed getting rid of those who had disabilities that made them unable to work or engage in war $^{15}$. In Sparta, Lycurgus decrees that children are state property and that those born 'puny and ill shaped' should be 'disposed of.'16. Winzer, M. A mentions in his article that Aristotle was led to characterize individuals who were deaf as "senseless and incapable of reason"; as "no better than the animals of the forest and unteachable"17. Aristotle wrote, "Men that are born deaf are in all cases dumb," and "Those who are born deaf all become senseless and incapable of reason." Aristotle's implication that the deaf could not possibly be taught to speak rendered them a tremendous disservice, since the next two thousand years of Christendom $^{18}$. His opinions and beliefs dictated scientific belief throughout the world until the 16 th century ${ }^{19}$. Superstitious beliefs and philosophers' opinion lead people to deprive persons with special needs from their rights. Invalid conception of people made exclusion disabled people from social interaction and assistance. Even killing the disabled people was not considered as an offence. Islam does not allow invalid conception and superstitious beliefs. As such Allah S.W.T forbids "O you, who believe ${ }^{20}$ abstain from many of the suspicions. Some suspicions are sins. And do not be curious (to find out faults of others), and do not backbite one another. Does one of you like that he eats the flesh of his dead brother? You would abhor it. And fear Allah. Surely Allah is MostRelenting, Very-Merciful"' (Al-Qur'ān 49:12). Islam never allows killing innocent person. The Holy Qur'ān reads Allah send divine law "whoever kills a person not in retaliation for a person killed, nor (as a punishment) for spreading disorder on the earth, is as if he has killed the whole of humankind, and whoever saves the life of a person is as if he has saved the life of the whole of humankind. Certainly, Our messengers have come to them with clear signs. Then, after all that, many of them are there to commit excesses on the earth" (Al-Qur'ān 5:32). Allah conferred dignity on the all human regardless. The Creator declares "And We bestowed dignity on the children of 'Adam” (Al-Qur'ān 17:70). Hence, the Qur'ānic teaching is human have to talk and belief based on

http://www.newstatesman.com/blogs/cripscolumn/2008/04/disabled-slaves-child-roman 13 Muhammad, M.Y. (2013).

14 Andrew H. (2013). A Disability History Timeline The struggle for equal rights through the ages.

15 Muhammad, M.Y. (2013).

16 Brignell V. (2008). See also: Andrew H. (2013).

17 Winzer, M. A. (1998). A tale often told: The early progression of special education. Remedial and Special Education, 19(4), 212-218

18 Kirchner, J. A. (1955). The Deaf and their Problems. The Yale journal of biology and medicine, 27(4), 312 .

19 Herrmann, J. A. (2006). Communicating in Silence: The Benedictine Roots of Deaf Education. Journal of Communication \& Religion, 29(1).

${ }^{20}$ Belief in six pillars of iman namely: (1) belief in Allah, (2) Angels, (3) Holy Books, (4) Messengers, (5) predestination and (6) on the Day of Judgment. 
trustworthy evidence such as divine revelation rather than void notion. Human is dignified by the Creator; humans have to be treated with honor by each other regardless. Protecting human life from illegal killing is a divine order and motivation. Rights of persons with special needs are established from the Qur'ānic outlook generally with all humans.

\section{IN ARAB SOCIETY}

The pre-Islamic Arabs used to kill their female babies for fearing of possible disgrace were less hardhearted and more compassionate toward those afflicted with difficulties and the chronically ill. They abstained from sharing food or sitting at a meal with those who had special needs. It is a historical background that the Arab society refused persons with special needs before revealed the Holy Qur'ān to last Prophet Muhammad (May Allah peace be upon him). In addition, people prevented the blind, lame and the diseased from sharing food with them. If persons with special needs asked for foods to the able person, they replayed them go to another door. On the one hand, people were deprived them from deserve standard lives; such as their right to setting and interaction with people, and so forth. On the other hand, few people used to like abstain themself from having food with disable, in fearing that they (few people) might come in eating with them of their (disable') food something ${ }^{21}$.

\section{IN INDIA SOCIETY}

Buckingham, in her history of disability in India, notes that in pre-modern India, disabled persons were denied inheritance in the higher levels of Hindu caste society. A dharmasastric text from the fourth century AD 'listed "a madman, an idiot, one born blind, and he who is afflicted by an incurable disease" as people who were rendered unable to inherit' because they were thought incapable of performing required family rituals ${ }^{22}$.

Ancient Hindu Law also mentions property and inheritance rights of disabled persons. They were excluded from inheritance in the eleventh-century Mitakshara ${ }^{23}$, and Miles further lists Hindu law books where disability and inheritance were mentioned ${ }^{24}$. For

21 Al-Alusi, S.M. (2007). Ruhul Ma'ni fi tafsir Qur'an al-A'zim wal sab' al-Masani, 14: 12.

22 Buckingham, J. (2011). "Writing Histories of Disability in India: Strategies of Inclusion." Disability \& Society 26 (4): 419-431. See also: Groce, N. E., London, J., \& Stein, M. A. (2012). Intergenerational Poverty and Disability: The implications of inheritance policy and practice on persons with disabilities in the developing world. Groce, N. E., London, J., \& Stein, M. A. (2014). Inheritance, poverty, and disability. Disability \& Society, 29(10), 1554-1568. See also: Groce, N. E., London, J., \& Stein, M. A. (2012). Intergenerational Poverty and Disability: The implications of inheritance policy and practice on persons with disabilities in the developing world. 23 Miles, M. (1999). "Some Historical Responses to Disability in South Asia and Reflections on. Service Provision; Focus on Mental Retardation in India, Pakistan and Bangladesh and Some Consideration of Blindness." PhD diss., University of Birmingham example, the Minor Law Books Narada (fourth/fifth century CE) notes exclusion of disabled persons from inheritance but asserts that they must be maintained and their sons must be allowed to remain inheritors ${ }^{25}$.

"Disability statistics were collected in the Census of India from as early as the late nineteenth century and the country had special schools that catered to the needs of people with disabilities from around the same time period. However, integration of people with disabilities and policy commitment to their participation as equals in society occurred only twenty-five years ago with the passage of four important laws". These included the Mental Health Act of 1987, the Rehabilitation Council of India Act of 1992, the People with Disabilities (Equal Opportunities, Protection of Rights and Full Participation) Act of 1995 (PWD Act), and the National Trust for Welfare of Persons with Autism, Cerebral Palsy, Mental Retardation and Multiple Disabilities Act of $1999^{26}$.

According to Dr. G. N. Karna 'In the Hindu doctrine of Karma Phala disability is sought to be linked with the retribution for the sins committed by individuals in the past ${ }^{27}$. He also stated that in a third world country like India, where maximum population is illiterate and narrow minded in their outlook; even disease is also associated with disobedience to natural or religious principles. In India, Hinduism is the most accepted religion of the people, and according to Hindu religion a person takes birth for several 'times' and it depends upon the deeds and activities he performs in one life. Disability occurs when one leads a very sinful life and as a result is subjected to the wrath and vengeance of God or Goddess $^{28}$.

There was discrimination against the disabled because they were unable to perform religious ceremonies. But that discrimination was not on religious ground as shudras who were not required to perform Vedic rites were also excluded from inheritance on grounds on disability ${ }^{29}$.

\section{Islamic ViewPoint on PeRsons With SPECIAL NeEdS}

Islamic philosophy has a kind hearted attitude towards Persons with special needs and those who are in a disadvantaged situation. The Qur'ān and the Hadith not only declared the

${ }^{24}$ Miles, M. (2008). Disability and Deafness in the Middle East. Annotated Bibliography. New York: Center for International Rehabilitation Research Information and Exchange. http:// cirrie.buffalo.edu/bibliography/mideast/.

25 Jolly, J., ed. (1889). The Minor Law Books, Part 1. Oxford: Clarendon

26 Menon, N., Parish, S. L., \& Rose, R. A. (2014). The "state" of persons with disabilities in India. Journal of Human Development and Capabilities, 15(4), 391-412. See also: World Bank. 2007. "People with Disabilities in India: From Commitments to Outcomes," Human Development Unit: South Asia Region: 1-186.

27 Karna, G. N. (1999). United Nations and the rights of disabled persons: a study in Indian perspective. APH Publishing.

${ }^{28}$ Karna, G. N. (1999).

29 Dutt, Ramesh Chandra, (1972). A History of Civilization in Ancient India, Delhi: Vistar Publishers, 1st Indian rep., p.59. 
favorable approaches and inclusion of disabilities as a natural part of human nature, but also provided principles and practical suggestions for caring for disabled people, as well as discussing the significance of such caring.

\section{Rights of PERSONS With SPECIAL NEEDS IN THE Holy QUR'ĀN}

The holy Qur'ān is a divine revelation that includes humans' dignity and justified rights regardless generally. It talks about persons with special needs their family bond, offspring, social integration, and life rights without discrimination of child-old, male-female, white-black, and rich-poor. The divine law had revealed upon the Prophet Muhammad (May Allah peace be upon him) in order to establish rights of persons with special needs in family, community and national level. As such Almighty Allah says: "There is no restriction on the blind, nor any restriction on the lame, nor any restriction on the sick, nor on yourselves, if you eat from your houses, or the houses of your fathers, or the houses of your mothers, or the houses of your brothers, or the houses of your sisters, or the houses of your father's brothers, or the houses of your father's sisters, or the houses of your mother's brothers, or the houses of your mother's sisters, or (from that) whereof you hold keys, or (from the house) of a friend. No sin on you whether you eat together or apart. But when you enter the houses, greet one another with a greeting from Allah, blessed and good. Thus Allah makes clear the Ayat to you that you may understand. " (AlQur'ān 24: Verse 61).

Interpretation of the verse in tafsir ibn Kathir: Allah S.W.T says "There is no restriction on the blind, nor any restriction on the lame, nor any restriction on the sick, 30 "

What is referred to here is the fact that they used to feel too embarrassed to eat with the blind, because they could not see the food or where the best morsels were, so others might take the best pieces before they could. They felt too embarrassed to eat with the lame because they could not sit comfortably, and their companions might take advantage of them, and they felt embarrassed to eat with the sick because they might not eat as much as others. So they were afraid to eat with them lest they were unfair to them in some way. 82 Then Allah revealed this Ayah, granting them a dispensation in this matter. This was the view of Sa'id bin Jubayr and Miqsam ${ }^{31}$. Ad-Dahhak said: "Before the Prophet's Mission, they used to feel too embarrassed and too proud to eat with these people, lest they might have to help them. So Allah revealed this Ayah." Abdur-Razzaq recorded that Mujahid said: "A man would take a blind, lame or sick person to the house of his brother or sister or aunt, and those disabled people would feel ashamed of

\footnotetext{
${ }^{30}$ Note. The italic text is the translation of verse 61: 24 .

31 Ibn Kathir A.F.I. (1999). Tafsir al-Qur'ān al-Azim, review: Sami Ibn Muhammad Salamah, publisher dar al-Taibati, 2nd edition. Vol. 6, P85. See also: English translation of Tafsir Ibn Kathir.

32 Ibn Kathir A.F.I. (1999).

33 Ibid

34 Abu-Abdullah Ahmad ibn Muhammad ibn Hambal, K., (1998). Masnad Ahmad ibn Hambal, publisher: Bayrut-
}

that and say, 'they are taking us to other people's houses.' So this Ayah was revealed granting permission for that. ${ }^{32 "}$

As-Suddi said: "A man would enter the house of his father or brother or son, and the lady of the house would bring him some food, but he would refrain from eating because the master of the house was not there, so Allah revealed: "There is no restriction on the blind" 33 . Allah S.W.T says: nor on yourselves, if you eat from your houses", This is stated here although it is obvious, so that from this starting point the houses of others may be mentioned, and to make it clear that the ruling applies equally to what comes after. Sons' houses are included in this even though they are not mentioned by name, and this is used as evidence by those who regard the son's wealth as being like the father's wealth. In the Musnad and the Sunan, it is reported through several routes that the Messenger of Allah said: You and your wealth belong to your father" 34 .

Allah S.W.T says: "or the houses of your fathers, or the houses of your mothers, or the houses of your brothers, or the houses of your sisters, or the houses of your father's brothers, or the houses of your father's sisters, or the houses of your mother's brothers, or the houses of your mother's sisters,". This is obvious, and this is used as evidence by those who think that it is obligatory for relatives to spend on one another ${ }^{35}$.

Allah S.W.T says: "or (from that) whereof you hold keys,". Sa'id bin Jubayr and As-Suddi said, "This refers to a people's servants, whether a slave or otherwise. There is nothing wrong with them eating from the food that is stored with them, within reason." Az-Zuhri narrated from Urwah that A'isha, may Allah be pleased with her, said, "The Muslims used to go out on military campaigns with the Messenger of Allah and they would give their keys to people they trusted and say, 'We permit you to eat whatever you need.' But they would say, 'It is not permissible for us to eat, they have given us permission reluctantly and we are only trustees.' Then Allah revealed "or (from that) whereof you hold keys)." 36

Allah S.W.T says: "or (from the house) of a friend”. Means, there is no sin on you if you eat from their houses, so long as you know that this does not upset them and they do not dislike $\mathrm{it}^{37}$. Allah S.W.T says: "No sin on you whether you eat together or apart”. Ali bin Abi Talhah reported from Ibn Abbas concerning this Ayah, "When Allah revealed the Ayah "O you who believe! Eat not up your property among yourselves unjustly," (Qur'ān 4: 29). The Muslims said, 'Allah has forbidden us to eat up our property among ourselves unjustly, and food is the best of property, so it is not permissible for anyone among us to eat at the house of anyone else.' So the people stopped doing that. Then Allah revealed: (There is no restriction on the blind,) until His statement; (or from the house of a friend) ${ }^{38}$. A man would also feel embarrassed and would refrain from eating alone until someone

Alamul kitab, 1st edition, No: 6608, vol: 14, p146. See also: Muhammad ibn Yazid Abu Abdullah al-Qzwyni, (2001). Sunan ibn Majah, review: Muhammad Fuad Abdu al-Baqi, Dar al-FikrBayrut, no. 2282, Vol. 7, P71.

35 Ibn Kathir.

36 Ibid

37 Ibid

38 Ibid 
else came along, but Allah made the matter easier for them and said: "(No sin on you whether you eat together or apart) ${ }^{39 "}$. Qatadah said, "This was a clan of Banu Kinanah who during the Jahiliyyah thought that it was a source of shame for one of them to eat alone, to such an extent that a man might keep on driving his laden camel even though he was hungry, until he could find someone to eat and drink with him. Then Allah revealed "No sin on you whether you eat together or apart)" ${ }^{40}$.

So this was a dispensation from Allah, allowing people to eat either alone or with others, even though eating with others is more blessed and is better." Imam Ahmad recorded from Wahshi bin Harb from his father from his grandfather that a man said to the Prophet, "We eat but we do not feel satisfied." He said: "Perhaps you are eating separately. Eat together and mention the Name of Allah, and He will bless the food for you" ${ }^{41}$. It was also recorded by Abu Dawud and Ibn Majah. Ibn Majah also recorded that Salim reported from his father from Umar, may Allah be pleased with him, that the Messenger of Allah said: "Eat together and not separately, for the blessing is in being together" 42 .

Allah S.W.T says: "But when you enter the houses, greet one another, with a greeting from Allah, blessed and good." Sa id bin Jubayr, Al-Hasan Al-Basri, Qatadah and Az-Zuhri said, "This means greet one another with Salam ${ }^{43 "}$. Allah S.W.T says: "Thus Allah makes clear the Ayat to you that you may understand". When Allah mentioned what wise rulings and reasonable, wellconstructed laws are contained in this Surah, He points out to His servants that He explains the Ayat to them clearly so that they may ponder them and understand their meanings ${ }^{44}$.

Thus, the Qur'ānic verse has been revealed as a complete mercy on the persons with special needs to console, relieve and support them. It saved them from the most dangerous psychological diseases that may impact them if they suffer from isolation and withdrawal from the social life ${ }^{45}$.

\section{CONTRIBUtion OF PROPHET MUHAMmAd (MAY AllaH PEACE BE UPON HIM) IN EMPOWERING PERSONS WITH SPECIAL NEEDS}

When the world was floundering between theories that called for execution of the mentally, disabled and other theories that called for employing them in drudgery, at that situation we see Prophet Mohammad (S.A.W) was merciful to this type of people ${ }^{46}$. Visiting the sick in general and the disabled in particular had been legislated by Islam for the purpose of relieving their

\footnotetext{
39 Ibid

40 Ibid

41 Abu-Abdullah Ahmad ibn Muhammad ibn Hambal, K., (1998). Masnad Ahmad ibn Hambal, publisher: BayrutAlamul kitab, 1st edition, No: 16078, vol: 25, p485.

42 Ibn Kathir

43 Ibid

44 Ibid

45 Al-Alusi, S.M. (2007) Ruhul Ma'ni fi tafsir Qur'an al-A'zim wal sab' al-Masani, 14: 12.

46 Md. Sirajul Islam and Sofiah Bt. Samsuddin, 12(6): 30-35.
}

suffering from both mental and physical ${ }^{47}$ (Muhammad M.Y). Prophet Muhammad (S.A.W) used to visit the sick, pray for them and console them, instill confidence in their souls, and fulfil their hearts and faces with happiness and joy. He could once go to someone in the outskirts of Madinah particularly to answer a simple need of a person that performing salah (prayer) in the house of an afflicted one, as granting of his request ${ }^{48}$. An example of this was Etban Ibn Malik (R.A). He was a blind man from Ansar. He asked to the Messenger of Allah (S.A.W) "I wish that you, O Messenger of Allah, would you come and perform salah in my house so that I would take it as a place of prayer. "As a reply, the Prophet may Allah peace be upon Him, promised to visit him and perform prayer, so humbly saying, "I will do, if Allah so wills". Etban said, "Allah's Messenger and Abu Bakar came early in the morning. Allah's Messenger asked for permission to enter, which I gave". Without sitting, he immediately entered and said, "In which part of your house do you like me to pray?" I pointed to a certain place in the house, so the Messenger of Allah stood and started praying and we, in turn, stood and he lined us in a row. He performed two-rak'ah prayer, ending it with taslim $^{49}$. This story informs that every human being has to appreciate the disables and try to fulfil their legal desires. It is a concrete example in appreciating the disability through responding their invitation, visiting them, and fulfilling their asking ${ }^{50}$.

The study has found by studying authentic texts of the Prophetic traditions that Prophet Muhammad (S.A.W) applied five unique moral approaches in empowering persons with special needs. First approach: Psychological improvement. Second approach: Establishing social integration. Third approach: Providing necessary legal services. Fourth approach: Teaching and Fifth approach: Employing ${ }^{51}$.

Furthermore, to be successful in these unique moral approaches He played twelve significant moral roles. These roles are generally variation on the following them: (1) Honoring them as humans without discrimination. (2) Special caring as they are special needs. (3) Careful about their rights. (4) Frequently visiting them (5) Consoling and psychotherapy them with prediction about reward the paradise. (6) Patience in answering their asking and dealing with them. (7) Inspiring the mass people to be cooperative with them and careful about their rights (8) Employing them according to knowledge, proficiency and ability without discrimination. (9) Governmental caring about responsibility to persons with special needs (10) Motivating them by employing.

${ }^{47}$ Al-Aoufi, H., Al-Zyoud, N., \& Shahminan, N. (2012). Islam and the cultural conceptualisation of disability. International Journal of Adolescence and Youth, 17(4), 205-219.

48Md. Sirajul Islam and Sofiah Bt. Samsuddin,12 (6): 30-35. See also: Al-Aoufi, H., Al-Zyoud, N., \& Shahminan, N. (2012). Islam and the cultural conceptualisation of disability. International Journal of Adolescence and Youth, 17(4), 205-219.

${ }^{49}$ Muhammad bin Ismail Abu Abdullah Al-Bukhari, (1987). AlJāmi As-Saḥịh al-Mukhtaṣr (Saḥị̣ al-Bukhari), review by Dr. Mustufa Daib al-Baga, Publisher: Bayrut-Darul Ibn kasir, 2nd edition. Vol. 1, p. 396, no. 1130.

$50 \mathrm{Md}$. Sirajul Islam and Sofiah Bt. Samsuddin, 12(6): 30-35. 51 Ibid 
(11) Fulfilling their legal and fair desires and (12) Praying to Allah for them ${ }^{52}$.

Omar Ibn Al-Khattab, the second Khalifah, who built a house for a blind man near the mosque after the father of the disabled boy complained to Omar about his son being unable to reach the mosque. A further example was in the second Islamic state in Damascus, when the Umayyad caliph, al Walid ibn Abd al Malik, established the first care home for intellectually disabled individuals. He also built the first hospital which accommodated the intellectually disabled as part of its services. He also assigned each disabled and needy individual a caregiver ${ }^{53}$. These moral approaches and moral roles were basis of necessary all forms of caring for disability. Hence, these approaches and roles are could be applicable in all societies around the world in empowering people with special.

\section{CONCLUSION}

This study has not attained any philosophy, principle, and approach in establishing social integration in reducing interpersonal problems of disability in ancient societies. Also, it has not found any effort in empowering persons with special needs in Europe, Arab and Indian society before revealing the Holy Qur'ān. It has achieved only in the Holy Qur'ān, Prophetic traditions and among his companions emphasized on caring persons with special needs in the early Islamic society in 7th century. Empowering this group of people is a major challenge in the current world. In view of such conditions, this study reminds the mass people to be responsible in empowering them in society. The study comprehends that caring and empowering them in society is human, religious, family, social and national responsibility. Everybody has to be positive, constrictive, cooperative and compassionate towards them in family, society, education institutes and everywhere.

\section{REFERENCES}

[1] Abu-Abdullah Ahmad ibn Muhammad ibn Hambal, K., 1998. Masnad Ahmad ibn Hambal, publisher: Bayrut- Alamul kitab, 1st edition.

[2] Al-Alusi, S.M. (2007) Ruhul Ma'ni fi tafsir Qur'ān al-A'zim wal sab' alMasani, 14: 12.

[3] Al-Aoufi, H., Al-Zyoud, N., \& Shahminan, N. (2012). Islam and the cultural conceptualisation of disability. International Journal of Adolescence and Youth, 17(4).

[4] Albrecht, G. (1992). The disability business: Rehabilitation in America. Newbury Park, CA: Sage Publications.

[5] Al-Jadid, M.S. (2013). Disability in Saudi Arabia. Saudi medical journal, 34(5).

[6] Andrew H. (2013). A Disability History Timeline The struggle for equal rights through the ages.

[7] Bhatty, I., Moten, A. A., Tawakkul, M., \& Amer, M. (2009). Disability in Islam: Insights into theology, law, history, and practice. Disabilities: Insights from across fields and around the world, 1, 157-176.

[8] Brignell V. (2008). Ancient World, published on The New Statesman website. column/2008/04/disabled-slaves-child-roman

\footnotetext{
52 Ibid
}

This publication is licensed under Creative Commons Attribution CC BY

http://dx.doi.org/10.29322/IJSRP.10.05.2020.p10137
[9] Buckingham, J. (2011). Writing Histories of Disability in India: Strategies of Inclusion. Disability \& Society 26 (4).

[10] Dutt, Ramesh Chandra. (1972). A History of Civilization in Ancient India, Delhi: Vistar Publishers, 1st Indian rep.,

[11] Groce, N. E., London, J., \& Stein, M. A. (2014). Inheritance, poverty, and disability. Disability \& Society, 29(10).

[12] Groce, N. E., London, J., \& Stein, M. A. Intergenerational Poverty and Disability: The implications of inheritance policy and practice on persons with disabilities in the developing world.

[13] Herrmann, J. A. (2006). Communicating in Silence: The Benedictine Roots of Deaf Education. Journal of Communication \& Religion, 29(1).

[14] Ibn Kathir A.F.I. (1999). Tafsir al-Qur'ān al-Azim, review: Sami Ibn Muhammad Salamah, publisher dar al-Taibati, 2nd edition.

[15] Jolly, J., ed. (1889). The Minor Law Books, Part 1. Oxford: Clarendon

[16] Karna, G. N. (1999). United Nations and the rights of disabled persons: a study in Indian perspective. APH Publishing.

[17] Karna, G. N. (1999). United Nations and the rights of disabled persons: a study in Indian perspective. APH Publishing.

[18] Kirchner, J. A. (1955). The Deaf and their Problems. The Yale journal of biology and medicine, 27(4).

[19] Mackelprang, R. W., \& Salsgiver, R. O. (1996). People with disabilities and social work: Historical and contemporary issues. Social work, 41(1).

[20] Md. Sirajul Islam and Sofiah Bt. Samsuddin. (2018). Moral Approaches and Roles of Prophet Muhammad (S.A.W) In Empowering Persons with Special Needs. Australian Journal of Basic and Applied Sciences, 12(6).

[21] Menon, N., Parish, S. L., \& Rose, R. A. (2014). The "state" of persons with disabilities in India. Journal of Human Development and Capabilities, 15(4).

[22] Miles, M. (1999). "Some Historical Responses to Disability in South Asia and Reflections on

[23] Miles, M. (2008). Disability and Deafness in the Middle East. Annotated Bibliography. New York: Center for International Rehabilitation Research Information and Exchange. http:// cirrie.buffalo.edu/bibliography/mideast/.

[24] Muhammad bin Ismail Abu Abdullah Al-Bukhari, (1987). Al-Jāmi` As-Sahịḥ al-Mukhtașr (Sahīh al-Bukhari), review by Dr. Mustufa Daib al-Baga, Publisher: Bayrut-Darul Ibn kasir, 2nd edition.

[25] Muhammad ibn Yazid Abu Abdullah al-Qzwyni, (2001). Sunan ibn Majah, review: Muhammad Fuad Abdu al-Baqi, Dar al-Fikr-Bayrut,

[26] Muhammad, A. (2007). The e-text version of the book The Message of The Quran.

[27] Muhammad, M.Y. (2013). The Prophet's Care for People With Special Needs, Available in http://www.usislam.org/islamicyouth/Muhammad/Prophet's\%20Care\%20fo r\%20People.htm, Retrieved on 5 September, 2013.

[28] Will R. (2013). Disability in Ancient Rome, available in http://www.rootedinrights.org/disability-in-ancient-rome/, retrieved $17 / 5 / 2016$.

[29] Winzer, M. A. (1998). A tale often told: The early progression of special education. Remedial and Special Education, 19(4).

[30] World Bank. (2007). "People with Disabilities in India: From Commitments to Outcomes," Human Development Unit: South Asia Region.

\section{AUTHORS}

First Author - Md. Sirajul Islam Ibn Sultan Ahmad, PhD candidate, Department of Qur'ān \& Sunnah Studies Studies, Kulliyyah of Islamic Revealed Knowledge and Human Sciences, International Islamic University Malaysia, 53100 Jalan Gombak, Selangor, Kuala Lumpur, Malaysia. E-mail:

sirajulislam1981@yahoo.com

${ }^{53}$ Al-Aoufi, H., Al-Zyoud, N., \& Shahminan, N. (2012). See also: Aljazoli, A. (2004). Islam position on disability. Morocco: ISESCO. 
Second Author - Sofiah Samsudin, Assistant Professor, Department of Qur'ān \& Sunnah, Kulliyyah of Islamic Revealed

Knowledge and Human Science, International Islamic University
Malaysia, 53100Jalan Gombak, Selangor, Kuala Lumpur, Malaysia. Email: sofiahs@iium.edu.my 